\title{
MULTICULTURALISM: A HUMAN RIGHTS-BASED APPROACH
}

\section{Vitalii Serohin}

\section{INTRODUCTION}

The modern state is a nation-state, that is, a sovereign political and legal organization of the people. However, the people, being as an organic unity within internal- and external political relations, as the bearer of a single political will, turns out on closer examination to be complex in ethnic, religious, ideological and many other features. At the same time, all modern states in the structural plan are organized around one or several dominant social groups, called state-forming, which, as a rule, constitute the majority of the population of the country and are the bearers of a certain culture, including language, religion, customs, mode of life, etc. From this point of view, even the states with a mono-national population, such as North and South Korea, Japan, or Scandinavian countries, are multicultural in a broad sense. The situation is even more complicated in the context of globalization, with unprecedented rates of population migration and cultural exchange. All this puts before the state and society the problem of finding the optimal interaction between the dominant (predominant) groups of the population, including titular ethnic groups, and national, linguistic and other cultural minorities.

Initially, the concept of a multicultural society had a rather clear ideological orientation: it reflected the growing concern of politicians, government officials and public figures that immigrants and their children could successfully integrate into society, despite existing differences in education, income, degree of involvement into state administration, political and religious views, etc. Multiculturalism was intended to protect the divided society from serious social conflicts, including from civil wars on ethnic and religious grounds, to promote the solidarity of a multinational and polyconfessional society, to guarantee its progressive development in terms of mutual enrichment of cultures. However, the problems of intercultural interaction have in no way lost their urgency over the past decades, when the policy of multiculturalism was proclaimed at national and international levels; moreover, they have become even larger and more diverse.

Unfortunately, the problems of multiculturalism are currently being discussed predominantly within the political aspect, while their practical resolution requires, as a rule, the transition into the legal sphere, into the plane of interpersonal, intergroup and inter-institutional relations. The fact is that a 
significant part of the individual's needs related to cultural identity are realized in the legal sphere; the behavior of people, where their cultural identity is manifested, is largely regulated by the norms of law and is embodied through certain forms of enforcement (use of rights, fulfillment of duties, observance of prohibitions). Accordingly, all participants in intercultural dialogue, in the legal sense, act as bearers of certain legal rights, freedoms and obligations, both individual and collective.

On this basis, the author of this article attempts to determine the ways of solving the problems of intercultural interaction precisely within the legal sphere. As the methodological basis, the author has offered to use the socalled "a human rights-based approach", which is to consider certain issues through the prism of guaranteeing human rights as the main criterion for social progress, the main indicator in assessing the level of development of the state and society. Such an approach is characterized by high humanism and, at the same time, is sufficiently effective to resolve specific cases arising in the law enforcement practice of various multicultural states.

\section{The Problem of Intercultural Interaction in Modern Society: the Main Causes of the Origin and Approaches to Solving}

Consideration of the problem of multiculturalism requires clarity in definitions, however it is difficult to accomplish this with regard to culture. In view of the extreme abundance of doctrinal approaches to the definition of the phenomenon of culture, let us refer to positive law. In accordance with the Mexico City Declaration on Cultural Policies (1982), the culture, in the broadest sense, can be viewed as "a combination of pronounced traits, spiritual and material, intellectual and emotional that characterize a society or social group. The culture encompasses, apart from art and literature, a way of life, fundamental human rights, value systems, traditions and faith" ${ }^{1}$. It seems appropriate to consider multiculturalism in the same context.

The presence of several, sometimes significantly different, cultures within one state system inevitably creates the need for a fundamental solution of the issue about their relationship and interaction. In terms of legal state system, this political decision, by its nature, must be embodied in the legal form, including the constitutional one.

There are three main approaches to solving the problem of intercultural interaction in the most general form: a) "dissolution" of cultural minorities among the total mass of dominant cultural groups (the principle of

\footnotetext{
${ }^{1}$ Mexico City Declaration on Cultural Policies. World Conference on Cultural Policies, Mexico City, 26 July - 6 August 1982. Retrieved from: https://culturalrights.net/descargas/ drets_culturals401.pdf (accessed 12.11.2019).
} 
assimilation); b) mutual "dissolution" of primary cultures together with the formation of a new, synthetic, nation-wide nation (the principle of a "meltingpot"); c) recognition and preservation of all cultural differences among all social groups (the principle of recognition and tolerance).

Starting from the second half of the XX century, the overwhelming majority of Western democracies prefer the latter way, which received the name of multiculturalism. Without going too deeply into the theory and history of the issue, we would like to note that multiculturalism in the generally accepted sense is a policy aimed at developing and preserving cultural differences in a single country and in the world in the whole, and the theory or ideology justifying such a policy; it is one of the aspects of tolerance, which consists in demanding the parallel existence of cultures for the purpose of their mutual penetration, enrichment and development within the universal direction of mass culture. Multiculturalism, applied to modern Europe, supposes, first of all, the inclusion of the elements of immigrants' cultures from the "third world" countries into its cultural field. The very concept of "multiculturalism" has been known since the 40's of the XX century, it became relevant in the 60's, and serious comprehensive studies of this phenomenon were deployed in the 90's - in the optimistic decade of multiculturalism, when it really seemed that it could be realized practically in any multicultural society.

It was originally planned that the children of migrant workers will persistently study in the education system of Western Europe and North America (to compensate their lower level of education and linguistic skills), will get decent work, compete with representatives of the titular nation on equal terms, will be inspired with the "national spirit" and finally will integrate into the political nation preserving their cultural identity. However, in practice, it happened quite differently: the descendants of migrant workers instead of integration, created their own mono-cultural groups, sufficiently closed to the outside environment - it was the situation with the Turks in Germany, Moroccans in the Netherlands, Algerians in France, Pakistanis in the UK and so on. Their representatives become active participants in street gangs, often have conflicts with neighbors or classmates and teachers, openly opposing themselves not only to the cultural traditions of the political nation, but also to the existing system of justice. It is not surprising that such facts, spread by the mass media, create and support negative stereotypes in society about cultural minorities and, of course, do not contribute to the promotion of multiculturalism in the public consciousness.

The re-actualization of multiculturalism theme has been recently explicitly linked to the migration crisis, especially in Europe. The supporters of this concept, in the case of immigrants, emphasize that multiculturalism is quite compatible 
with the integration of immigrants into society, and does not contradict it, since it provides more fair conditions for immigrants' integration.

However, the beginning of the XXI century was marked by a serious disappointment with the policy of multiculturalism throughout Europe, clearly manifested in the official statements of the heads of the states and governments in Great Britain, Germany, France and other countries.

The reasons for the disappointment, of course, were significant. Thus, according to the results of a sociological survey conducted in 2009 by the order of the German government among migrants, the Turks, who make up more than half of the 6.8 million immigrants in Germany, are worse integrated in the German society than all others. It turned out, for example, that every fourth Turks in Germany does not know German, and every second almost does not communicate with the Germans. The situation with education is not better: $67 \%$ of the Poles, $60 \%$ of the Greeks and $44 \%$ of the Italians living in Germany, have completed secondary education, and only $41 \%$ of the Turks have the secondary education. At the same time, the number of the Turks living on social benefits is up to $15 \%$ in their group, while among the Greeks this indicator is only $7.5 \%$. According to German Interior Minister Thomas de Maiziere, $10-15 \%$ of migrants in Germany openly refuse to integrate into German society ${ }^{2}$.

The problem of multiculturalism remains relevant for Ukraine, however for a few other reasons. There is no problem of a massive wave of migrants in Ukraine, mainly due to a serious social and economic crisis, but there is a problem of interethnic and inter-confessional relations. So, according to the latest population census (2001), Ukrainians make up the majority of the national population of Ukraine, their number is about 37.54 million people ( $77.8 \%$ of the total population). However, almost $15 \%$ of citizens, who identified themselves as Ukrainians by nationality (that is, every sixth), indicated Russian as their native language. The number of representatives of other nationalities in Ukraine is about 11 million people $(22.2 \%$ of the total population). The most numerous of them are Russians, Jews, Belarusians, Moldovans, Bulgarians, Poles, Hungarians, Romanians, Greeks, Tatars, Armenians and Gypsies. The Russians occupy the first place among the national minorities in Ukraine -8.3 million people, or $17.3 \%$ of the total population. At the same time, almost all citizens, naming themselves Russians by nationality $(96 \%)$, indicated Russian as their native language ${ }^{3}$.

${ }^{2}$ Turki plokho integriruyutsya v Germanii [Turks poorly integrate in Germany]. InterRight. April 17, 2010. Retrieved from: http://inright.ru/news/id_984 (accessed 12.11.2019) (in Russian).

${ }^{3}$ Pro kiljkistj ta sklad naselennja Ukrajiny za pidsumkamy Vseukrajinsjkogho perepysu naselennja 2001 roku [About the number and composition of the population of Ukraine according to the results of the 2001 All-Ukrainian Population Census]. Retrieved from: http://2001.ukrcensus.gov.ua/ results/general/nationality/ (accessed 12.11.2019) (in Ukrainian). 
At the same time, Ukraine has been and remains a multi-confessional state with a wide structure of faiths. Nowadays there are about 37 thousand religious organizations of 55 confessional lines on its territory ${ }^{4}$. Each confession, by definition, has its own characteristics, differences, its doctrinal paradigm and cult system. These features and differences become most visible in the process of the relationship between different confessions as components of a single poly-confessional religious space of society.

It comes as no surprise, when Charles Taylor - the world-famous philosopher, professor at McGill University in Canada, one of the "gurus of multiculturalism", who came to Ukraine in the summer of 2013, suggested that the future of our country is "in the diversity of a multicultural context" . "If Ukraine can recognize the existence and coexistence of such diversity in the country, this will be its great strength, both for building its future and for having its role in the region", he said.

At the same time, discussions about the acceptability and necessity of multiculturalism are still go on. The supporters of multiculturalism see it as a manifestation of humanism, tolerance and pluralistic democracy, a way of ensuring intercultural harmony and guaranteeing the rights of various kinds of minorities. In turn, the critics of this policy say that multiculturalism leads to cultural expansion, the complete destruction of the centuries-long cultural backgrounds, developed cultural traditions, or, at best, to the eclectic averaging and universal assertion of global, national and impersonal mass culture. According to them, if the low level of cultural development of migrants is undoubtedly increased, then the high level of culture of the country taking multiculturalism is invariably falling. Besides, in practice it turns out that multiculturalism, highlighting certain groups and providing resources for strengthening ethnic communities and organizations, destroys the social unity and divides the community itself ${ }^{6}$.

\footnotetext{
${ }^{4}$ Pro stan i tendenciji rozvytku relighijnoji sytuaciji ta derzhavno-konfesijnykh vidnosyn $\mathrm{v}$ Ukrajini za 2012 rik: Informacijnyj zvit Ministerstva kuljtury Ukrajiny [On the Status and Trends of the Development of the Religious Situation and State-Confessional Relations in Ukraine in 2012: Information Report of the Ministry of Culture of Ukraine]. Retrieved from: http://www.irs.in.ua/index.php?option=com_content\&view=article\&id=1212\%3A1\&catid=51\%3 Astats\&Itemid $=79 \&$ lang $=$ uk (accessed 12.11.2019) (in Ukrainian).

5 Charl'z Teylor: «V raznoobrazii mul'tikul'turnogo konteksta - budushchee Ukrainy» [Charles Taylor: "In the diversity of multicultural context - the future of Ukraine"]. Zerkalo nedeli Зеркало недели [Mirror of the week]. 2013. Vol. 24. June 26 - July 5. URL: https://zn.ua/socium/charlz-teylor-v-raznoobrazii-multikulturnogo-konteksta-buduscheeukrainy-_html (accessed 12.11.2019) (in Russian).

${ }^{6}$ Eisenberg A. (2006) Equality, trust and multiculturalism. Social Capital, Diversity, and the Welfare State / F. Kay and R. Johnson (eds). Vancouver: University of British Columbia Press, 2006, pp. 67-68.
} 
Sometimes supporters and opponents of multiculturalism find fundamentally different qualities there. For example, some antimulticulturalists, such as Brian Barry and Samuel Huntington, say that multiculturalist ideas are inherently illiberal - ie., that multiculturalism is based on a repudiation of Enlightenment values of individual freedom, democratic citizenship and universal human rights, and it is precisely this repudiation of core Enlightenment principles which explains why multiculturalists seek to challenge traditional Western models of national citizenship in the name of cultural difference. At the same time multiculturalists, vice versa, accept that multiculturalism is rooted in familiar liberal-democratic ideals of equality, freedom and citizenship, and indeed aims precisely to address the many ways in which full equality and citizenship are denied to minorities.

J. Rex and G. Singh describe two opposing views on multiculturalism. "The soft look" is illustrated by a favorable phrase often used by politicians: "We now live in a multicultural society". Multiculturalism according to that statement is viewed as a natural continuation of liberal democracy and democratic values of tolerance and respect for diversity. Conversely, the "hard look" views multiculturalism, with its emphasis on the group over the individual, as a threat to liberal and democratic values and, therefore, believes that economic migrants or political migrants and refugees can be regarded as threatening the unity of society ${ }^{7}$. At the same time, most experts are inclined to some "middle point of view" that views multiculturalism, or at least the recognition and tolerance of different expressions of culture, as one, perhaps the only possible mean for Western countries in order to cope with the problems arising in regard to globalization, mass immigration and increasing number of ethnic minorities within their borders.

All these views can be observed in various degrees in different European countries. For example, Britain is often regarded as the most developed form of multiculturalism, where Britons, at least according to official policy, stand for a society that provides equal status to certain cultural and religious groups without the domination of any culture. UK law allows ensuring the legitimation of a significant number of minorities such as blacks, Asians, Muslims, etc. and even provide special legal protection to the members of such groups. Conversely, France is often perceived as the main supporter of the assimilation of European nations.

Critics often argued that multiculturalism is the segregation and creation of "parallel communities" and it should be replaced by "civic integration"

${ }^{7}$ Rex, J., Singh, G. (2003) Multiculturalism and political Integration in Modern Nation States. International Journal of Multicultural Societies, Vol. 5(1), p. 4. 
approach based on such postulates as linguistic requirements and citizenship tests (Joppke 2004, 2007). Multiculturalism theorists always insisted that multiculturalism for immigrant groups is aimed not at segregation, but at the integration method aimed at fairer inclusion conditions. Thus, there is no significant contradiction at the conceptual level between multiculturalism policy and civic integration policy, and indeed such countries as Canada and Australia always had an effective integration policy alongside with their decades-old multiculturalism policy.

It should be borne in mind that any state policy, including multiculturalism, is mainly implemented through legal instruments. Legal instruments occupy the leading role for the states that declare themselves as legal at the constitutional level. In this regard, the state's legal policy in the field of intercultural relations and those conceptual approaches that are the basis for such a policy are of particular importance. In our opinion, "a human rights-based approach", which essence, content and perspectives will be revealed in the following section of our research, should be the main, systemforming approach for the formation of the legal policy of Ukraine, as well as of other European states.

\section{2. "A Human Rights-Based Approach" to Resolving Intercultural Interaction: Nature, Content, Perspectives for Implementation}

One of the key problems of multiculturalism is the guaranteeing of human rights, in particular the achievement of a public consensus on the totality of human rights, which is mandatory for all members of society regardless of any cultural differences. At the same time, the supporters of consistent multiculturalism pay attention on collective, group human rights, for example, on the right of ethnic and religious groups to observe their customs within the relations between men and women, including the duty of ladies to wear veils and the subordinate position of women in the family. The supporters of the priority of individual human rights are, for example, against discrimination against women, against wearing explicit items of religious affiliation in unreligious schools, etc.

One should admit that the rhetoric of "the right of every culture to selfexpression" can hide not only the tendency to self-isolation, but also possible totalitarian claims. Taking into account the liberal origin of multiculturalism, one may use a shocking at first sight statement: "If the cannibal culture is in no way inferior to the liberal culture, then a liberal should be ready to throw himself under the bus"8.

${ }^{8}$ Lukovskaya D.I. (2007) Problema universal'nosti prav cheloveka [The issue of the universality of human rights]. Istoriya gosudarstva i prava [History of State and Law], no. 12, pp. 32-35 (in Russian). 
It is important to note that multiculturalism, by its very nature, is contrary to the principle of the universality of human rights. Therefore, from the international and legal, constitutional and legal points of view, the search for acceptable solutions should be in moderate versions of multiculturalism that are completely compatible with the very principle of respect for human rights. Accordingly, multiculturalism is not the basis for comprehensive tolerance. In this regard, the official policy of multiculturalism practiced in Canada is preferable, where the Pierre Trudeau government in 1971 held a course for multiculturalism under the slogan "One nation, two languages, many peoples and cultures"9. In 1988, Canada even passed a special Act on multiculturalism, which clearly stated that "multiculturalism highlights the principle of universalism, that is, the thing that unites us is more important than our differences. But multiculturalism is not the basis for the comprehensive tolerance". In accordance with the official policy of multiculturalism in Canada, ethnic differences are admitted and accepted by the state only to the extent when individuals (not groups) can identify themselves with the cultural tradition of their choice, but only if this identification does not violate human rights, the rights of others or the laws of the country ${ }^{10}$.

Unjustified "flirting" of the state with representatives of cultural minorities, especially in the legal sphere, involves extremely negative consequences. Bright examples of this kind are given by O.N. Bublik and D.L. Coleman ${ }^{11}$. So, an American of Japanese descent drowned two young children and tried (unsuccessfully) to commit suicide because of her husband's betrayal - the court admitted these actions as corresponding to the ancient Japanese custom and practically justified her, and charged her to one year of imprisonment, which she spent being under investigation. In accordance to another criminal case, the court acquitted an American of Chinese descent for killing a wife because of her infidelity, finding these actions consistent with the Chinese custom of washing away the shame with blood. In a third criminal case, an American of Laotian descent was kidnapped from her job and forced to have sexual intercourse - a Lao descent immigrant was sentenced to 120 days of imprisonment and 900 dollars of

9 Terborn G. (2001) Mul'tikul'turnye obshchestva. [Multicultural Societies]. Sotsiologicheskoe obozrenie [Sociological Review], vol. 1, no. 1, pp. 50-51 (in Russian).

${ }^{10}$ Cryderman B.K., Fleras A., O'Toole C.N. (1998) Police, Rase and Elhnicity. A Guide for Law Enforcement Officers. Toronto; Vancouver: Butter-worths, p. 20.

${ }^{11}$ Coleman D.L. (1996) Individualizing Justice through Multiculturalism: The Liberals' Dilemma. Columbia Law Review, vol. 96, no. 5, pp. 1093-1167; Bibik O.N. (2012). Vvedenie v kul'turologiyu ugolovnogo prava [Introduction to the Cultural Studies of Criminal Law]. Moscow: Yurlitinform, $352 \mathrm{p}$. 
compensation for the caused damage, as his tribe considered such a way of choosing the bride to be ordinary. It seems that it is hard to imagine more damage to the legal foundations of society, including the principles of equality, legality and the rule of law!

In this regard, we have to refer to the UNESCO Universal Declaration on Cultural Diversity (2001), which proclaims in the Art. 4: "The defence of cultural diversity is an ethical imperative, inseparable from respect for human dignity. It implies a commitment to human rights and fundamental freedoms, in particular the rights of persons belonging to minorities and those of indigenous peoples. No one may invoke cultural diversity to infringe upon human rights guaranteed by international law, nor to limit their scope"12.

We are deeply convinced that the recognition of a certain range of special (group, corporate) rights in any cultural communities should in no way prejudice the universality and fundamental nature of human rights as the fundamental principle of any national legal order. In this regard A.A. Marchenkov fairly notes "in the world, where everything is relative, where everything has shifted from one place to another and is in the constant motion, human rights are a standing point, a system of universal legal and ethical coordinates, where society can determine the degree of its suitability for a civilized, worthy existence. The existence and recognition of the "basic nature" of the values of human rights sort of "restrain" postmodern reality"13. Besides, it should be borne in mind that there are very different ideas in traditional cultures about individual's values in general, and about human rights and freedoms in particular, about the individual's limits of freedom and the limits of his bondage to traditions and religious beliefs; and these representations can not be quickly and easily changed. However, if there is no deep certainty in the society that the rules of the game are the same for everyone, then there won't be mutual trust, which is one of the most essential prerequisites for solidarity.

It should be noted that the problem of ensuring the rights of representatives of cultural minorities in the overwhelming majority of cases is, in fact, not a problem of ensuring the basic rights of a person and citizen, but

${ }^{12}$ UNESCO Universal Declaration on Cultural Diversity. Adopted by the 31 st Session of the General Conference of UNESCO, Paris, 2 November 2001. Retrieved from: http://www.unesco.org/new/fileadmin/MULTIMEDIA/HQ/CLT/pdf/5_Cultural_Diversity_EN.pd $\mathrm{f}$ (accessed 12.11.2019).

13 Marchenkov A.A. (2006) Obrazovanie pravozashchitnoorientirovannykh kommunikativnykh soobshchestv cherez tekst [Formation of human rights-based communication communities through text]. Proceedings of the Prava cheloveka $v$ kontekste rossiyskoy modernizatsii: mezhregional'naya nauchno-prakticheskaya konferentsiya (Russia, Permian, May 17-18, 2006). Retrieved from: http://old.pgpalata.ru/reshr/grow/04.shtml (in Russian) (accessed 12.11.2019). 
rather the matter of the limits and forms of their implementation. Indeed, the ban on riding motorbike without a protective helmet is not so much a restriction of the human right to an individual external image (as part of the right to privacy), but a manifestation of the elementary care about a person's life, taking into account all those dangers associated with traffic. Therefore, a person wearing a turban should clearly define what is more important for him: "purity of the image" or the opportunity to become a biker. Similarly, a Muslim woman has every right to wear a veil, unless the nature of public relations requires a clear identification of a person (photographing for obtaining a passport or other identity document, passing customs and passport control, participation in meetings, demonstrations and other mass actions, etc.). The rejection of the corresponding limits of the exercise of the rights and freedoms by a representative of a particular cultural group is identical with the rejection of the existing legal order. Accordingly, this person is obliged either to measure his behavior to the existing law and order, or to emigrate searching such a law and order that best corresponds to his group (corporate) rights.

Will Kymlicka quite correctly emphasizes that existing theories of "liberal multiculturalism" explicitly or indirectly assume "desecuritized" relations between the state and minorities, that is, these relations are viewed as social policy issues that should normally be resolved within democratic process of making demands, their discussion and making decisions, not as national security issues that go beyond the normal democratic process ${ }^{14}$. However, political and legal practice indicates the opposite: multiculturalism after the events of September 11, 2001, had to co-exist in the context of increasingly "securitized" relations between the state and cultural minorities. Even though terrorism has no nationality, and thousands of immigrants from European countries (English, French, Germans, Russians, etc.) fought within the ISIGS, however, is strongly associated in the public consciousness (largely due to the media's propaganda role) with Muslims and the Arab world, and states are compelled to respond to this in their domestic and foreign policies, in international and legal acts and in national law. Accordingly, the fight for the preservation of cultural identity can not be a cover for the dissemination of views and practices that threaten the democratic system and universally recognized human rights.

In this regard, it should also be noted that multiculturalism, in its extremely liberal version, which viewed representatives of cultural minorities, including immigrants, as persons who arrived for permanent residence,

${ }^{14}$ Kymlicka W. (2014) The Essentialist Critique of Multiculturalism: Theories, Policies, Ethos. Robert Schuman Centre for Advanced Studies Research Paper no. RSCAS 2014/59, p. 18. Retrieved from: http://dx.doi.org/10.2139/ssrn.2441133 (accessed 12.11.2019). 
socially useful work and loyal to the constitutional system of the hosting state, gradually lost its relevance under the influence of the latest challenges posed by mass illegal migration, transnational crime and international terrorism pretending for own state system. Accordingly, liberal multiculturalism is replaced by rationalized and securitized multiculturalism, which allows to reconcile cultural diversity with national and democratic legal state system, sustainable development and promotion of human rights.

Multicultural societies of the early XXI century, under the influence of mass migration and the flow of special demands based on tolerance for cultural diversity, faced a real threat to the erosion of national identity. And there are many examples of this: a significant increase in the number of Africans among French and Dutch citizens, an excess of mosques over the number of Christian temples in the UK capital, and, of course, the massive spread of "national blocks" (Chinese, Russian, Arab, etc.) in the United States, Canada and the European Union countries. In the context when the share of the "newly arrived" population is steadily increasing due to migration and the "demographic boom" among newcomers, occurring against the background of low birth rates among representatives of the titular nation, each multicultural state will sooner or later faces the dilemma of further national development: whether to preserve national identity formed by centuries of previous historical development, or to follow the "covenants of the ancestors", and, accordingly, to give preference to the policy of "dissolution" of newly arrived cultural minorities, or to continue the policy of multiculturalism, which in the current demographic realities will inevitably change the "status quo" and transform the national identity into a qualitatively new one. It should be noted that such a change in the cultural "status quo" has occurred many times within historical retrospective; it is enough to remember at least how the cultural appearance of the territory of modern Spain has changed from antiquity to the late Middle Ages. Therefore, it is necessary to treat changes in the cultural appearance of the country as an element of the historical process, but the decision must be ultimately made by the people. It is another matter that the choice must be conscious, and science, including jurisprudence, has to play a significant role in this matter.

Rationalized multiculturalism implies the creation of an effective organizational and legal mechanism that includes a proper regulatory basis, a branched network of legitimate public authorities and civil society institutions, as well as law enforcement practices that transfer cultural diversity into a sustainable system of justice. At the same time, the regulatory basis of a multicultural society should have several levels, each of them would have commensurate methods of ensuring social order. 
The upper level of normative regulation is made up by the Constitution and other acts of constitutional legislation (including international legal acts that have become part of national legislation), which establish the basis for the legal status of the individual, including the basic (constitutional) rights and freedoms of the individual. And this level, as have already been mentioned, is not only a matter of the national legal order, but also a matter of international obligations of the state. Consequently, this upper level of normative and legal regulation can not be the subject matter of "political bargaining" between the state and cultural communities, however powerful and plural they might be. The basic principle of a person's legal status - is the principle of equality can not be the subject matter to revision.

The medium level of normative regulation is national legislation, special (sectoral) status of certain categories of subjects, not dependent on their cultural self-identification (participants in civil circulation, traffic, criminal justice, etc.). These norms can establish a special procedure of wearing uniform, special ceremonial, rules for handling dangerous substances, etc. Participation of representatives of these or those cultural communities in these legal relations compels them, if necessary, to remove their "cultural mask", subordinating their behavior to the rules that are common to all homogeneous subjects. In case of a contradiction between these norms and the corporate rules of cultural communities, representatives of the latter may simply refuse to participate in the relevant legal relations (to cease the relevant special status) and thus, independently resolve the conflict that has been revealed.

Finally, the third, lower level of normative regulation is the norms that establish the rights of cultural communities (national, linguistic, religious, etc.). Will Kymlicka refers them as "group differentiated rights"15. At the same time, the special status of these groups should correlate with the constitutional status of the individual. If we are talking about the rights of certain socially vulnerable layers of the population (including various kinds of minorities, as well as pensioners, disabled people, the poor, etc.), then the privileges granted to them (as a manifestation of positive discrimination and at the same time social character of the state) should be exclusively compensatory in nature, that is, to ensure equalization of the real situation of this category of persons in comparison with other persons, based on their lower "starting opportunities". A classic example of this kind can be the rights of national minorities, provided for by the Declaration of the Rights of

${ }^{15}$ Kymlicka W. (1989) Liberalism, Community, and Culture. Oxford: Oxford University Press, 290 p. 
Nationalities in Ukraine $(1991)^{16}$ and the current Law of Ukraine "On National Minorities" (1992) $)^{17}$.

It should be added to the foregoing that not every activity of cultural communities is legally significant, and therefore, is the subject of normative and legal regulation. The length of the outerwear, the color of the turban, either to wear a veil or not while staying in the own apartment, - these issues are outside the legal scope and, therefore, are not the subject to legal assessment.

\section{CONCLUSIONS}

The conducted research of the relevant problems of implementing the policy of multiculturalism in the legal plane makes it possible to conclude the following:

1. Despite serious criticism from academic circles, multiculturalism remains the backbone of the development of intercultural relations in developed Western democracies. At the same time, liberal multiculturalism is replaced by realistic, "securitized" multiculturalism, which soundly assesses intercultural relations in terms of national security threats, democratic system and universally recognized human rights.

2. Rationalized multiculturalism implies the creation of an effective organizational and legal mechanism, including a proper regulatory basis, a branched network of legitimate public authorities and civil society institutions, as well as law enforcement practices that transfer cultural diversity into a stable system of justice. At the same time, the regulatory basis of a multicultural society must be complex in nature and include at least three levels: the first - is the constitutional, which is the basis for the fundamentals of legal position of an individual, the second - is the level of national legislation, which enshrines the special (sectoral) status of certain categories of subjects that are independent from their cultural self-identification, and the third - is the level of legislation that enshrines the rights of cultural communities.

3. The recognition of a particular range of special (group, corporate) rights over certain cultural communities should in no way call into question the universalism and fundamentality of human rights as the key pillar of any national system of justice. The problem of guaranteeing the rights of

${ }^{16}$ Deklaracija prav nacionaljnostej Ukrajiny [Declaration of Rights of Nationalities of Ukraine], adopted November 1, 1991. Retrieved from: http://zakon.rada.gov.ua/laws/ show/177112 (accessed 12.11.2019) (in Ukrainian).

${ }_{17}$ Pro nacionaljni menshyny v Ukrajini [About national minorities in Ukraine]: Law of Ukraine of June 25, 1992 no 2494-XII. Retrieved from: http://zakon.rada.gov.ua/laws/show/249412 (accessed 12.11.2019) (in Ukrainian). 
representatives of cultural minorities in the vast majority of cases is not a problem of ensuring basic human and civil rights, but rather the issue on the limits and forms of their realization. The rejection of the relevant limits of realizing the rights and freedoms by a representative of a particular cultural group is identical with the rejection of the existing system of justice.

\section{SUMMARY}

The article deals with relevant problems of legal regulation of intercultural relations arising in the modern multicultural society. The basic approaches to the evaluation of multiculturalism and its influence on the development of democratic rule of law state system are analyzed. As a methodological basis, the author offers to use the so-called "a human rights-based approach", which is to consider certain issues through the prism of guaranteeing human rights as the main criterion for social progress, the main indicator while assessing the level of development of the state and society. It has been noted that the regulatory basis of a multicultural society within such an approach should include three levels: the first - the constitutional one, which establishes the basics for the legal status of an individual, the second - the level of national legislation establishing the special status of certain categories of subjects, independent of their cultural self-identification and the third one - the level of legislation enshrining the rights of cultural communities.

The author has grounded the conclusion that the recognition of a particular range of special (group, corporate) rights over certain cultural communities should in no way call into question the universalism and fundamentality of human rights as the key pillar of any national system of justice, and the problem of ensuring the rights of representatives of cultural minorities is reduced to the issue about the limits and forms of their implementation. Accordingly, each participant of intercultural legal interaction is obliged either to harmonize own behavior with the existing system of justice, or to emigrate in search of such system of justice that best fits his or her group (corporate) rights.

\section{REFERENCES}

1. Mexico City Declaration on Cultural Policies. World Conference on Cultural Policies, Mexico City, 26 July - 6 August 1982. Retrieved from: https://culturalrights.net/descargas/drets_culturals401.pdf (accessed 12.11.2019).

2. Turki plokho integriruyutsya $v$ Germanii [Turks poorly integrate in Germany]. InterRight. April 17, 2010. Retrieved from: http://inright.ru/ news/id_984 (accessed 12.11.2019) (in Russian).

3. Pro kiljkistj ta sklad naselennja Ukrajiny za pidsumkamy Vseukrajinsjkogho perepysu naselennja 2001 roku [About the number and 
composition of the population of Ukraine according to the results of the 2001 All-Ukrainian Population Census]. Retrieved from: http://2001.ukrcensus.gov.ua/results/general/nationality/ (accessed 12.11.2019) (in Ukrainian).

4. Pro stan i tendenciji rozvytku relighijnoji sytuaciji ta derzhavnokonfesijnykh vidnosyn v Ukrajini za 2012 rik: Informacijnyj zvit Ministerstva kuljtury Ukrajiny [On the Status and Trends of the Development of the Religious Situation and State-Confessional Relations in Ukraine in 2012: Information Report of the Ministry of Culture of Ukraine]. Retrieved from: http://www.irs.in.ua/index.php?option=com_content\&view=article\&id=1212 $\% 3 \mathrm{~A} 1 \&$ catid $=51 \% 3$ Astats\&Itemid=79\&lang=uk (accessed 12.11.2019) (in Ukrainian).

5. Charl'z Teylor: "V raznoobrazii mul'tikul'turnogo konteksta budushchee Ukrainy" [Charles Taylor: "In the diversity of multicultural context - the future of Ukraine"]. Zerkalo nedeli Зеркало недели [Mirror of the week]. 2013. Vol. 24. June 26 - July 5. URL: https://zn.ua/socium/charlzteylor-v-raznoobrazii-multikulturnogo-konteksta-buduschee-ukrainy-_.html (accessed 12.11.2019) (in Russian).

6. Eisenberg A. (2006) Equality, trust and multiculturalism. Social Capital, Diversity, and the Welfare State / F. Kay and R. Johnson (eds). Vancouver: University of British Columbia Press, 2006, pp. 67-94.

7. Rex, J., Singh, G. (2003) Multiculturalism and political Integration in Modern Nation States. International Journal of Multicultural Societies, Vol. 5(1), pp. 3-19.

8. Lukovskaya D.I. (2007) Problema universal'nosti prav cheloveka [The issue of the universality of human rights]. Istoriya gosudarstva $i$ prava [History of State and Law], no. 12, pp. 32-35 (in Russian).

9. Терборн Г. Мультикультурные общества. Социологическое обозрение. 2001. № 1. Т. 1. С. 50-51.

10. Cryderman B.K., Fleras A., O’Toole C.N. (1998) Police, Rase and Elhnicity. A Guide for Law Enforcement Officers. Toronto; Vancouver: Butter-worths, $234 \mathrm{p}$.

11. Coleman D. L. (1996) Individualizing Justice through Multiculturalism: The Liberals' Dilemma. Columbia Law Review, vol. 96, no. 5 , pp. $1093-1167$.

12. Bibik O. N. (2012). Vvedenie v kul'turologiyu ugolovnogo prava [Introduction to the Cultural Studies of Criminal Law]. Moscow: Yurlitinform, $352 \mathrm{p}$.

13. UNESCO Universal Declaration on Cultural Diversity. Adopted by the 31st Session of the General Conference of UNESCO, Paris, 2 November 
2001. Retrieved from: http://www.unesco.org/new/fileadmin/MULTIMEDIA/ HQ/CLT/pdf/5_Cultural_Diversity_EN.pdf (accessed 12.11.2019).

14. Marchenkov A.A. (2006) Obrazovanie pravozashchitnoorientirovannykh kommunikativnykh soobshchestv cherez tekst [Formation of human rights-based communication communities through text]. Proceedings of the Prava cheloveka $v$ kontekste rossiyskoy modernizatsii: mezhregional'naya nauchno-prakticheskaya konferentsiya (Russia, Permian, May 17-18, 2006). Retrieved from: http://old.pgpalata.ru/reshr/grow/04.shtml (in Russian) (accessed 12.11.2019).

15. Kymlicka W. (2014) The Essentialist Critique of Multiculturalism: Theories, Policies, Ethos. Robert Schuman Centre for Advanced Studies Research Paper no. RSCAS 2014/59, p. 18. Retrieved from: http://dx.doi.org/10.2139/ssrn.2441133 (accessed 12.11.2019).

16. Kymlicka W. (1989) Liberalism, Community, and Culture. Oxford: Oxford University Press, 290 p.

17. Deklaracija prav nacionaljnostej Ukrajiny [Declaration of Rights of Nationalities of Ukraine], adopted November 1, 1991. Retrieved from: http://zakon.rada.gov.ua/laws/show/1771-12 (accessed 12.11.2019) (in Ukrainian).

18. Pro nacionaljni menshyny $\mathrm{v}$ Ukrajini [About national minorities in Ukraine]: Law of Ukraine no 2494-XII, adopted June 25, 1992. Retrieved from: http://zakon.rada.gov.ua/laws/show/2494-12 (accessed 12.11.2019) (in Ukrainian).

\section{Information about the author:} Vitalii Serohin, Doctor in Law, Professor, Professor at the Constitutional and Municipal Law Department of the School of Law,

V.N. Karazin Kharkiv National University

4, Svobody Sq., Kharkiv, 61022, Ukraine ORCID ID: orcid.org/0000-0002-1973-9310 